\title{
Revisiting clay mineral evidence for an expansion of biotic soils in the late Neoproterozoic
}

\author{
MEHRNOUSH RAFIEI, STEFAN LÖHR
}

Macquarie University, Sydney, Australia, mehrnoush.rafiei@hdr.mq.edu.au

Macquarie University, Sydney, Australia, stefan.loehr@mq.edu.au

Detrital clays, the most abundant components of finegrained sedimentary rocks, form primarily via chemical weathering in biologically active soils and have been widely used as palaeoweathering proxies. However, Earth's terrestrial surface has been devoid of biologically active soils for most of its history. The well-documented influence of simple multicellular organisms such as fungi and lichen on chemical weathering in modern settings informs the hypothesis that an apparent late Neoproterozoic increase in shale clay mineral abundance, as inferred from bulk samples $\mathrm{XRD}$ analyses showing an increased ratio of phyllosilicates to quartz, is due to an expansion of biologically active soils [1]. This hypothesis has been challenged by subsequent work which has attributed this increase in clay mineral abundance to increased deposition of mechanically weathered primary mica rather than secondary pedogenic clays [2], arguing that this is more consistent with reduced chemical weathering associated with increased uplift and physical weathering during the latest Neoproterozoic. Here we revisit this question using a new electron microbeam-based imaging and mineral mapping approach that is able to (semi)quantitatively separate detrital, pedogenic and authigenic clay phases. We apply this approach to three shales from the Adelaide Rift Complex (Enorama Shale, Brachina Formation, Bunyeroo Formation), spanning the time-interval previously interpreted to show increased pedogenic clay production. Our results clearly identify a dominance of mechanical-weathering derived $2 \mathrm{M}$ illite and mica within the detrital clay fraction of the late Cryogenian and lower Ediacaran shales, accompanied by a high abundance of detrital feldspar and (potentially detrital) chlorite. However, a marked increase in the amount of secondary soil-sourced illite in the mid Ediacaran Bunyeroo Formation, and the near-absence of readily weathered phases such as feldspar and chlorite, is consistent with the clay mineral factory hypothesis of [1] arguing for biologically mediated chemical weathering. We note, however, that our results identify an increase in chemical maturity and pedogenic clay abundance in the mid-Ediacaran, rather than the basal Ediacaran as previously argued [1].

[1] Kennedy et al. (2006), Science 311, 1446-1449. [2] Tosca et al. (2010), Geochimica et Cosmochimica Acta 74, 15791592. 